\title{
A null-model analysis of the spatio-temporal distribution of earthworm species assemblages in Colombian grasslands
}

\section{Thibaud Decaëns*,1, Juan José Jiménez $†$ and Jean-Pierre Rossił}

\author{
* Laboratoire d'Ecologie - EA 1293 ECODIV, UFR Sciences et Techniques, Université de Rouen, F-76821 Mont Saint Aignan Cedex, France \\ $\dagger$ Instituto Pirenaico de Ecología-CSIC, Avda. Regimiento Galicia, s/n. E-22700, Jaca (Huesca), Spain \\ $\ddagger$ INRA - UMR BIOGECO, Domaine de l'Hermitage Pierroton, 69 route d'Arcachon, F-33612 Cestas, France \\ (Accepted 6 March 2009)
}

\begin{abstract}
Earthworm assemblages are usually spatio-temporally structured in mosaics of patches with different species composition. We re-analysed results of past research carried out in Eastern Colombia to explore how interspecific competition accounts for this pattern. In three sown pastures and three native savannas, density data matrices were obtained from spatially explicit samplings at several successive dates, and spatio-temporal patterns of species assemblages were described through partial triadic analyses and geostatistics. This first analysis detected assemblage patchiness in the six plots at spatial scales ranging from 6 to $33 \mathrm{~m}$. Species richness ranged from 5 to 6 species per plot. Null models were further used to analyse niche overlap and morphometric distribution patterns at two different scales, i.e. at the 'plot level' and the 'patch level'. Seasonal and vertical niche overlaps were higher than expected by chance at both scales, indicating high environmental constraints on assemblage membership. Within-patch overlaps were lower than plot-scale overlaps. Biometric niche overlap was random at the plot level and was weakly lower than that expected by chance in patches. Body weight was significantly overdispersed and constant whatever the scale, while body length and diameter showed a similar trend within patches. These results suggest that earthworms form distinct assemblages within patches, mainly driven by deterministic responses to competition: ecologically similar species avoid competition through spatial segregation, whereas a minimal level of ecological segregation is required to allow co-existence in a given patch.
\end{abstract}

Key Words: community ecology, interspecific competition, niche overlap analysis, scale dependence, size distribution analysis

\section{INTRODUCTION}

The study of the spatial pattern of soil biota and the factors by which they are governed is a key research area in understanding the structure and function of soil biodiversity and their relationships with above-ground processes (Ettema \& Wardle 2002, Ettema et al. 2000). To date however, soil communities have been minimally considered in spatial ecology when compared with aboveground biota (Ettema \& Wardle 2002). As an example, despite the early recognition of the fundamental role played by earthworms in soil processes (Darwin 1881), the very first descriptions of their spatial distribution were published as late as the 1950s (Boyd 1957, Guild 1951). Earthworm spatial patterns are however likely to contribute to existing heterogeneity in soil resources

\footnotetext{
${ }^{1}$ Corresponding author. Email: thibaud.decaens@univ-rouen.fr
}

and microhabitats, and to promote species co-existence through greater resource partitioning (Lavelle 1996, 2002; Wardle 2002). In this sense earthworms could be keystone organisms in soil faunal communities (Lavelle et al. 2006).

In recent studies, spatial statistics have been used to describe the horizontal spatial patterning of earthworm assemblages at local scales (i.e. habitat surfaces of about 1 ha). In most cases, species are aggregated in patches over ranges of 20-50 m, each of them characterized by a dominant species assemblage that seems to be temporally stable for about 20 mo (Decaëns \& Rossi 2001, Hernández et al. 2007, Jiménez et al. 2001, 2006a; Margerie et al. 2001, Nuutinen et al. 1998, Rossi 2003, Rossi \& Lavelle 1998). The determinants of these patterns are hardly identified as they probably imply both environmental and population or community factors operating and interacting at different scales (Barot et al. 2007). For instance, species-assemblage patchiness may result from 
species responses to the heterogeneity in plant cover and soil properties (Margerie et al. 2001, Phillipson et al. 1976, Poier\&Richter 1992), intrinsic population processes such as reproduction rates and limited dispersal (Barot et al. 2007, Jiménez et al. 2001, Rossi et al. 1997, Whalen \& Costa 2003), or interspecific competition leading to spatial segregation between species pairs with high niche overlap (Jiménez \& Rossi 2006, Jiménez et al. 2006a).

The implication of interspecific interactions, in particular competition, in shaping the structure of natural communities has been reported for many animals and plants (Connell 1983, Diamond 1975, Goldberg \& Barton 1992, Gotelli \& McCabe 2002, Schoener 1974, Wilson \& Habiba 1995). According to the theoretical framework of interspecific competition, two basic predictions may be formulated (Gotelli \& Ellison 2002): first, among a set of communities or species assemblages, species should co-occur less often than expected by chance (EBC) (Diamond 1975, Pielou \& Pielou 1968); second, within a community or species assemblage, co-existing species should present a lower niche overlap than EBC (Schoener 1974). Classic examples of the latter include limitation of similarity in body size or in multi-trait morphology (Hutchinson 1959, MacArthur \& Levins 1967, Weiher \& Keddy 1995, Weiher et al. 1998). Nonrandomness in niche overlap and co-occurrence patterns is thus considered to reflect competition constraints on community assembly. Recently, null model analysis has emerged as an efficient tool to identify nonrandom community patterns (Gotelli 2001, Gotelli \& Graves 1996). They are pattern-generating models that deliberately exclude a mechanism of interest (for instance competition), and allow testing of observed data against randomized null communities (Gotelli 2001, Gotelli \& Graves 1996). They were successfully used to highlight and interpret, among others, non-random patterns in body-size distribution (Feeley 2003, Gotelli \& Ellison 2002) and niche overlap (Albrecht \& Gotelli 2001, Hofer et al. 2004) in different animal assemblages.

In this paper, we re-analysed with null models the data collected in the course of different studies of the spatio-temporal distribution of earthworm assemblages in Colombian tropical grasslands (Decaëns 1999, Decaëns \& Rossi 2001, Jiménez 1999, Jiménez et al. 2006a). All these studies described a consistent horizontal patterning in alternated patches dominated by particular species assemblages. We hypothesized that these patches result from predictable assembly rules related to interspecific competition, i.e. are a consequence of spatial exclusion among competing species. If so, segregation should be most evident, based on the degree of niche overlap, at local scales ('patch-level assemblages', i.e. the list of dominant species characterizing a given patch), and less so at larger scales ('plot-level assemblages', i.e. the list of species present in a given grassland plot). We thus expected to observe two types of non-random patterns: (1) within-patch niche overlap should be lower than EBC and lower than plot-scale overlap (MacArthur \& Levins 1967, Weiher \& Keddy 1995); (2) morphometric distance (size ratio) between species co-existing in a given patch should be higher and more constant than EBC, and higher and more constant than at the plot level (Brown \& Wilson 1956, Dayan \& Simberloff 2005, Gotelli \& Ellison 2002, Hutchinson 1959). We tested this hypothesis for different dimensions of the niche (seasonal activity, vertical distribution and multi-trait morphology) and by separately analysing different biometric traits.

An alternate hypothesis is that patchiness reflects environmental heterogeneity and that patch-level assemblages are composed of species sharing the adapted traits to the patch environment. In this case, dominating species of a given patch should present a higher niche overlap than EBC and than at the plot-scale (Keddy 1992, Weiher \& Keddy 1995). Morphometric distance within a given patch should also be lower and less constant than EBC and lower and less constant than for plot-level assemblages.

\section{STUDY SITE}

A data set was compiled from two studies carried out at the CIAT-CORPOICA Carimagua Research Station, in the phytogeographic unit of the well-drained isohyperthermic savannas of eastern Colombia $\left(4^{\circ} 37^{\prime} \mathrm{N}\right.$, $71^{\circ} 19^{\prime} \mathrm{W}, 175 \mathrm{~m}$ asl). Climate is subhumid tropical with a mean annual rainfall and temperature of $2280 \mathrm{~mm}$ and $26{ }^{\circ} \mathrm{C}$, respectively (1972-1995, CIAT data). Study plots were located in an upland area with a well-drained silty clay Oxisol (Tropeptic Haplustox Isohyperthermic; USDA classification), characterized by its acidity $\left(\mathrm{pH}\left[\mathrm{H}_{2} \mathrm{O}\right]=4.5\right)$, a high Al saturation $(>80 \%)$ and low values of exchangeable cations. All the study plots were located in the same area of the Research Station, with no more than $100 \mathrm{~m}$ between each other.

Sampling was carried out in three savanna plots and three sown pastures. Savanna plots (Savanna 1 to 3) were all devoid of any management, and had areas of 0.36 (Savanna 2 and 3) and 2.26 ha (Savanna 1). Vegetation was dominated by the Poaceae Andropogon bicornis L., Gymnopogon foliosus (Wild.) Nees, Panicum sp., Trachypogon sp. and Imperata brasiliensis Trin. Pasture 1 was a 1 ha and 18-y-old plot of Urochloa decumbens (Stapf) R.D. Webster (Poaceae) and Pueraria phaseoloides Benth. (Fabaceae), grazed by cattle at an average stocking rate of 1.75 Animal Unit (AU) ha ${ }^{-1}(1 \mathrm{AU}=250 \mathrm{~kg})$. Pasture 2 was a 0.72 ha and 3-y-old plot of Urochloa humidicola (Rendle) Morrone \&Zuloaga (Poaceae), Arachis pintoi Krap. \& Greg (Fabaceae), Stylosanthes capitata Vog. (Fabaceae) and Centrosema acutifolium Benth. 'Vichada' 
(Fabaceae), grazed by cattle at an average stocking rate of $2 \mathrm{AU}^{-1}$. Pasture 3 was a 0.72 ha and 1-y-old plot of Panicum maximum and A. pintoi, managed similarly to pasture 2 .

\section{METHODS}

\section{Earthworm sampling}

In each plot, samples were taken on a regular grid of evenly spaced points. The dimension of the grids varied depending on plot size: $8 \times 8$ sampling points each $10 \mathrm{~m}$ in Pasture 1 and Savanna 1; $8 \times 15$ points each $5 \mathrm{~m}$ in Pastures 2 and 3; $4 \times 15$ points each $5 \mathrm{~m}$ in Savanna 2 and 3. Each plot was surveyed at different successive dates: November 1993, 1994 and May 1995 for Savanna 1; September 1993, October 1994 and June 1995 for Pasture 1; and every 2 mo from October 1995 to August 1997, with exception of December 1995 and July 1997. in the other plots. Thus, the total study period for each plot ranged from 21 to 22 mo.

At each point, a soil monolith of $40 \times 40 \mathrm{~cm}$ (Savanna 1 and Pasture 1) or $25 \times 25 \mathrm{~cm}$ (other plots) was dug out down to $30-\mathrm{cm}$ depth and hand sorted in the field. Collected earthworms were identified, counted and replaced in the monolith point with the sorted soil. Prior to the monolith extraction, the density of the large species Martiodrilus sp. was estimated by counting its fresh casts at the surface of a $1-\mathrm{m}^{2}$ square that was centred on the monolith (Jiménez et al. 1998a). Soil monoliths at subsequent dates were taken in points separated about $30-50 \mathrm{~cm}$ from the sample of the first date. This displacement in space was considered negligible at the scale of the plot, and sampling coordinates were taken as identical from one date to another.

As the characteristics of samples varied significantly among plots, we used non-parametric regression (using Ecosim software, Acquired Intelligence Inc. \& KeseyBear, http://garyentsminger.com/ecosim.htm) to verify that differences in observed patterns were not a byproduct of different sampling procedures. This procedure was run to test the effect of sampling grid size, distance between sampling points, sample sizes and sampling frequency (dependent variables) on patch spatial range (independent variable). Non-parametric regression fits a standard linear regression to the data set, and then uses randomization to test the null hypothesis that the slope, intercept or correlation coefficient equals 0 . In all cases, slope, intercept and correlation coefficient were as EBC $\left(r^{2}=0.00 ; P=0.457\right.$ for grid size, $r^{2}=0.58 ; P=0.129$ for distance effects, $\mathrm{r}^{2}=0.58 ; \mathrm{P}=0.140$ for sample size, $\mathrm{r}^{2}=0.58 ; \mathrm{P}=0.147$ for sampling frequency). The different sampling designs were thus assumed to address processes at similar spatial scales.
For niche overlap calculations, we used the data sets obtained by Jiménez (1999) from a stratified random sampling performed from April 1994 to September 1995 in the Savanna 1 and Pasture 1. In each plot, five monthly $1-\mathrm{m}^{2}$ monoliths were dug out down to $50 \mathrm{~cm}$ and hand sorted in 10-cm increment layers. Two $20 \times 20 \times 20$-cm soil cores were sampled $1 \mathrm{~m}$ distance from the monolith; the soil was then washed and sieved to collect small species that were not efficiently collected by hand sorting (Jiménez et al. 2006b). Earthworms were fixed and stored in $4 \%$ formaldehyde, identified and counted in the laboratory to calculate mean population density for each sampling month and in each soil layer. Body length $(\mathrm{mm})$, weight $\mathrm{g}$ ) and preclitellar diameter $(\mathrm{mm})$ were measured on fixed specimens for all specimens that were complete. Voucher specimens of all species were deposited in the Universidad Tecnologica de Pereira (Colombia). For both the grassland and the savanna, we obtained three matrices describing species according to their temporal dynamics over a complete seasonal cycle (July 1994-June 1995), vertical distribution and biometric traits.

\section{Partial triadic analyses and identification of patch-level assemblages}

The partial triadic analysis (PTA) is used to analyse a chronological series of tables that describes the same objects with the same variables (Kroonenberg 1989, Rossi 2003, Thioulouse \& Chessel 1987). It allows extraction of the multivariate structure that is expressed through the different dates, and describes dominant patterns in its first axes while relegating the random noise to further axes that are not retained for interpretation (Rossi 2003). For each plot, we used $t$ matrices ( $t=$ number of sampling dates), each one describing $n$ observations (sampling points) for $p$ variables (species abundances). Each PTA consisted of two successive steps: (1) The interstructure analysis provided a global description of the sampling points as a function of the typology of the sampling dates. For each species and in each plot, spatial patterns that were stable over the study period were described by mapping the coordinates of the sampling points on the first interstructure axis on the sample grid. (2) The compromise analysis provided a description of sampling points as a function of the species typology. It was used for each plot to identify the species assemblages that characterized similar patches at different dates, to which we refer herein as the "patch-level assemblages'. On the first compromise axis, a patch-level assemblage was defined as a group of species displaying coordinates of the same sign. The maps of the coordinates of the sampling points on the first compromise axis thus described the spatio-temporal distribution of these patchlevel assemblages. 
All the computations and figures were processed with the module STATIS and other graphical modules of the software ADE-4 (Thioulouse et al. 1997).

\section{Moran's autocorrelogram}

For each PTA, we tested the presence of spatial autocorrelation in species assemblages using Moran's correlograms (Legendre \& Fortin 1989, Sokal \& Oden 1978) computed with the sample scores on the first compromise axis (Decaëns \& Rossi 2001). The correlogram shows the changes of autocorrelation coefficients with increasing distance. It thus indicates the spatial range of the observed spatial patterns and provides a test of the significance for non-randomness (Sokal \& Oden 1978). Data were allocated to nine (Pasture 1 and Savanna 1), 12 (Savannas 2 and 3) or 14 (Pasture 2 and 3) distance classes depending on the size of the analysed matrix. Moran's index was calculated using the 'Autocorrélation 3.03' module of the 'R Package' (Université de Montréal, Canada), and the normality of the data distribution was tested with a KolmogorovSmirnov test before computation with the 'VerNorm 3.0' module of the same software. When necessary, the BoxCox transformation was used to reduce the asymmetry of the frequency distribution (Sokal \& Rohlf 1995).

\section{Temporal and vertical niche overlap analysis}

Niche overlap analysis was undertaken for the six plotlevel assemblages and the twelve patch-level assemblages identified by the compromise analyses. For each of them, we built an individual matrix in which rows and columns represented species and niche categories, respectively, and we tested if niche overlap significantly differed from the corresponding value under the null hypothesis (i.e. random assemblage). We used Pianka's index (Pianka 1973) and the Czechanowski index (Feinsinger et al. 1981). For species $\mathrm{j}$ and $\mathrm{k}$, with resource utilizations $\mathrm{p}_{\mathrm{ji}}$ and $\mathrm{p}_{\mathrm{ki}}$, Pianka's overlap index of species $\mathrm{j}$ on species $\mathrm{k}$ $\left(\mathrm{O}_{\mathrm{jk}}\right)$ is given by the following formula:

$$
O_{j k}=O_{k j}=\frac{\sum_{i=1}^{n} p_{j i} p_{k i}}{\sqrt{\sum_{i=1}^{n}\left(p_{j i}^{2}\right)\left(p_{k i}^{2}\right)}}
$$

For species $\mathrm{j}$ and $\mathrm{k}$, with resource utilizations $\mathrm{p}_{\mathrm{ji}}$ and $\mathrm{p}_{\mathrm{ki}}$, Czechanowski overlap index $\left(O_{j k}\right)$ is:

$$
O_{j k}=O_{k j}=1.0-0.5 \times \sum_{i=1}^{n}\left|p_{j i}-p_{k i}\right|
$$

The level of niche breadth was calculated with both indices for three distinct dimensions of resource utiliza- tion. (1) Although temporal partitioning may be relatively uncommon in animal communities (Schoener 1974), several examples involving invertebrates have been described to date (Gotelli \& Graves 1996). We considered that time was of potential importance for earthworm assemblages because the high seasonal fluctuations of important resources, such as water and litter, may cause diet shifts according to the time of the year. For this analysis, we used the seasonal dynamics data. Each individual matrix was a table where rows and columns represented species and months respectively. Table entries were the average number of individuals collected for each species at a given month. (2) Niche partitioning according to species vertical distribution is a common feature in soil animal communities (Lavelle \& Spain 2001, Wardle 2002). When foraging at different depths, earthworm species may reduce competition by feeding on different types of organic resources (Bouché 1977). Vertical niche partitioning among Carimagua's earthworms has been suggested by Jiménez \& Decaëns (2000), who found that the average living depth differed substantially among species. To quantify and test vertical niche overlap, we used individual matrices in which rows and columns represented species and soil strata, respectively, and where entries consisted of the mean number of individuals collected in each stratum over the total study period. As most species were not represented below $40 \mathrm{~cm}$, we performed the analysis with the data of the first three 10-cm layers, and bulked the deeper layers into a single '<30 cm' category. (3) In ecological communities, ecologically similar species that are also morphologically alike might not co-exist because of excessive overlap in their resource uses (Hutchinson 1959). Consequently, biometric traits have been widely used to quantify the influence of competition on community assembly (Dayan \& Simberloff 2005). Biometric niche overlap was calculated for individual matrices where rows and columns represented species and biometric traits, respectively, and where the entries consisted of the mean trait values measured for the collected individuals. Here, we used three traits (body length, weight and preclitellar diameter) that describe earthworm external morphology in a reliable way (Jiménez 1999). To avoid any influence of the measurement units in the index calculation, data were previously standardized by dividing each value by the standard deviation of the corresponding column in the matrix.

Mean niche overlap was calculated for each patch- and plot-level assemblage and compared with a null model in which the observed data were randomized among species (10 000 iterations). If competitively structured, a given assemblage should present less niche overlap than $\mathrm{EBC}$ for the dimensions of the niche that are subject to competition. We used a randomization algorithm that retains the niche breadth of each species, but randomizes 
which particular resource states are utilized (RA3 in Albrecht \& Gotelli 2001). It corresponds to a simple reshuffling of each row of the matrix that assumes all the different resource states to be equally abundant (or usable) by all species. Calculations and tests were done with the 'Niche Overlap' module of Ecosim.

\section{Size distribution analysis}

We tested if identified assemblages presented patterns that limit biometric similarity between co-existing species for the three morphometric traits that were used in the niche overlap analysis. For each trait, we calculated: (1) the minimum segment length (MSL), which is the smallest size difference found in all available pairs of species; (2) the variance in segment length (VarSL) that measures the overall tendency for the trait values to be evenly spaced. Both metrics were successively computed after log-transforming the data, which allowed analysing the size ratio of the considered trait (Gotelli \& Ellison 2002). Observed values were calculated for all assemblages that comprised more than two species, and were compared with those obtained for 10000 random assemblages. In a competitively structured community or assemblage, MSL and VarSL should be higher and lower than EBC, respectively (Gotelli \& Ellison 2002). We used a null model algorithm which takes the largest and smallest species in the assemblage to set the minimum and maximum boundaries for the simulation. The remaining $(n-2)$ species were chosen from a random, uniform distribution within these limits. This null model assumes that in evolutionary time, any possible configuration of body sizes is equiprobable within the limits imposed by the largest and smallest species (Gotelli \& Ellison 2002). Calculations and tests were done with the 'Size Overlap' module of Ecosim.

\section{Data comparisons}

For each index (Pianka's and Czechanowski $\mathrm{O}_{\mathrm{ik}}$, MSL, VarSL), we calculated the standardised effect size (SES):

$$
S E S=\frac{\left(I_{o b s}-I_{\text {sim }}\right)}{S_{\text {sim }}}
$$

where $I_{\text {sim }}$ is the mean index of the simulated assemblages, $S_{\text {sim }}$ is the standard deviation, and $I_{\text {obs }}$ is the observed index (Gotelli \& Graves 1996). For each type of assemblage (patch-level or plot-level) and each index, we further calculated the average values of the observed and simulated indices, and the average corresponding SES.

We used a permutation test to compare: (1) the average values of the observed indices with those of simulated assemblages; (2) the average observed values obtained in patch-level assemblages with those obtained for plot-level assemblages. A similar approach was used to test whether average SES values obtained for a given set of assemblages did differ from zero or not. Each test involved 10000 iterations in which the data were reshuffled among the categories to determine how much variation was expected among the means. The null hypothesis was that the observed variation among the means of the groups was no greater than EBC. Calculations were performed using the 'Anova' module of Ecosim.

\section{RESULTS}

\section{Earthworm assemblage composition}

A total of six species, all still undescribed and all native from the study region, was identified in the six sampled plots (Jiménez 1999). Apart from Andiorrhinus sp., which occurred only in Pasture 1 and Savanna 1, all species were present in all the plots (Tables 1 and 2). Mean total earthworm density and biomass respectively ranged from $16-25$ ind. $\mathrm{m}^{-2}$ and $1.7-4.2 \mathrm{~g} \mathrm{fw} \mathrm{m}^{-2}$ in the savannas, and 45-97 ind. $\mathrm{m}^{-2}$ and 5.5-62.1 $\mathrm{g} \mathrm{fw} \mathrm{m}^{-2}$ in the pastures. Detailed studies of species assemblage composition in the different study plots have been published previously in Decaëns \& Jiménez (2002) and Jiménez et al. (1998b). The highest densities were recorded for Glossodrilus sp. and, in the pastures, Ocnerodrilidae sp. Depending on the

Table 1. Main features of the spatio-temporal distribution of earthworm communities in the six study plots as described by the partial triadic analyses. CPI1 = first axis of the interstructure analysis; $\mathrm{CPC} 1$ = first axis of the compromise analysis; Moran's $\mathrm{P}=$ significance level of the spatial patterns.

\begin{tabular}{|c|c|c|c|c|c|}
\hline Plots & $\begin{array}{l}\text { Number } \\
\text { of species }\end{array}$ & $\begin{array}{l}\% \text { inertia } \\
\text { CPI1 }\end{array}$ & $\begin{array}{l}\% \text { inertia } \\
\text { CPC1 }\end{array}$ & $\begin{array}{l}\text { CPC1 patch } \\
\text { range } \\
\text { (metres) }\end{array}$ & $\begin{array}{c}\text { CPC1 } \\
\text { Moran's P }\end{array}$ \\
\hline Pasture 1 & 6 & 44.9 & 28.1 & 22.0 & $<0.001$ \\
\hline Pasture 2 & 5 & 20.2 & 34.2 & 22.4 & $<0.001$ \\
\hline Pasture 3 & 5 & 17.9 & 35.3 & 11.2 & 0.003 \\
\hline Savanna 1 & 6 & 38.4 & 33.1 & 33.0 & $<0.001$ \\
\hline Savanna 2 & 5 & 14.6 & 36.4 & 11.9 & $<0.001$ \\
\hline Savanna 3 & 5 & 12.9 & 36.6 & 6.0 & 0.002 \\
\hline
\end{tabular}

Table 2. Composition of the species assemblages in the six study plots. For a given plot, species with the same letters belong to the same patch-level assemblage as identified by the first component of the compromise analysis $(\mathrm{a}=$ species with positive scores; $b=$ species with negative scores). Species codes: And = Andiodrilus sp.; Anr = Andiorrhinus sp.; Aym $=$ Aymara sp.; Glo = Glossodrilus sp.; Mar = Martiodrilus sp.; Ocn = Ocnerodrilidae.

\begin{tabular}{lcccccc}
\hline & Ocn & Mar & Glo & And & Aym & Anr \\
\hline Pasture 1 & a & b & a & b & b & a \\
Pasture 2 & a & a & a & b & b & - \\
Pasture 3 & b & b & a & a & b & - \\
Savanna 1 & b & b & a & b & b & a \\
Savanna 2 & a & b & b & a & a & - \\
Savanna 3 & a & a & b & b & b & - \\
\hline
\end{tabular}




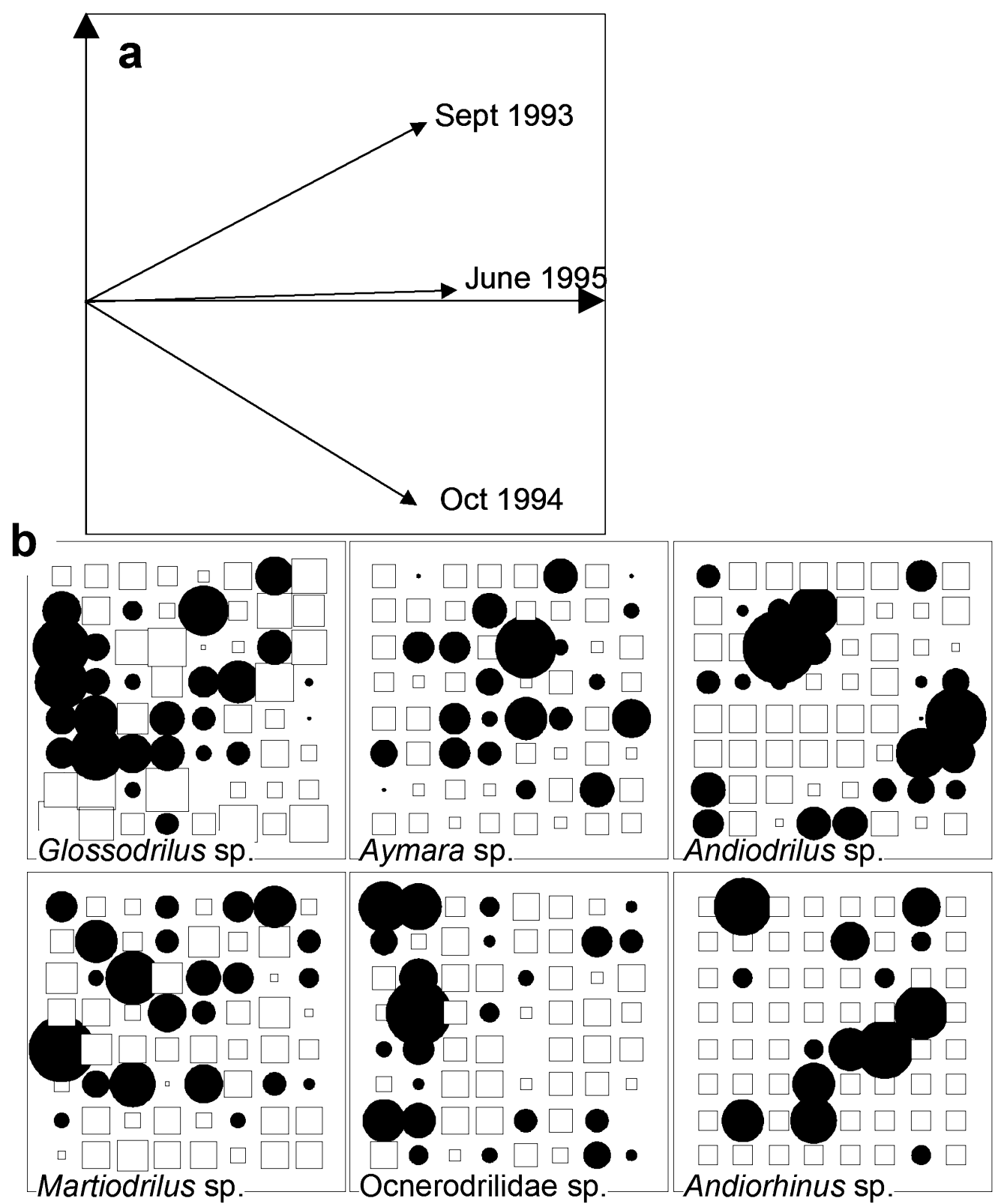

Figure 1. Interstructure analysis of the species assemblage structure in pasture 1: ordination of sampling dates on the plan defined by the first two axes of the PCA on the interstructure matrix (a); maps of the factorial coordinates of the 64 sampling points on the first axis of the interstructure analysis for each of the six species identified in the pasture (b) (circles and squares represent positive and negative scores and the size is proportional to the corresponding value). Modified from Figure 1 in Jiménez et al. (2006) Acta Oecologica 30: 299-311. Copyright (c) by Elsevier. Reprinted with permission of the publisher.

plot, the highest contributions to biomass were recorded for Glossodrilus sp., Andiodrilus sp. or Martiodrilus sp., the latter being dominant in the three pastures.

\section{Earthworm assemblage spatial patterns}

The percentages of the total inertia explained by the first axes of the PTA's interstructure and compromise analyses are presented in Table 1 . Values were always lower than $50 \%$, indicating relatively little inertia in the data. Interstructure analyses described the patterns of population distribution that were stable across time. Most species were significantly aggregated, but highdensity patches had sharper boundaries for endogeic species (e.g. Glossodrilus sp., Andiodrilus sp.), and were more diffuse for surface-dwelling species (Aymara sp. and Martiodrilus sp.) (Figure 1). Compromise analyses described the species assemblage patterns that were stable across time, and highlighted clusters of species 

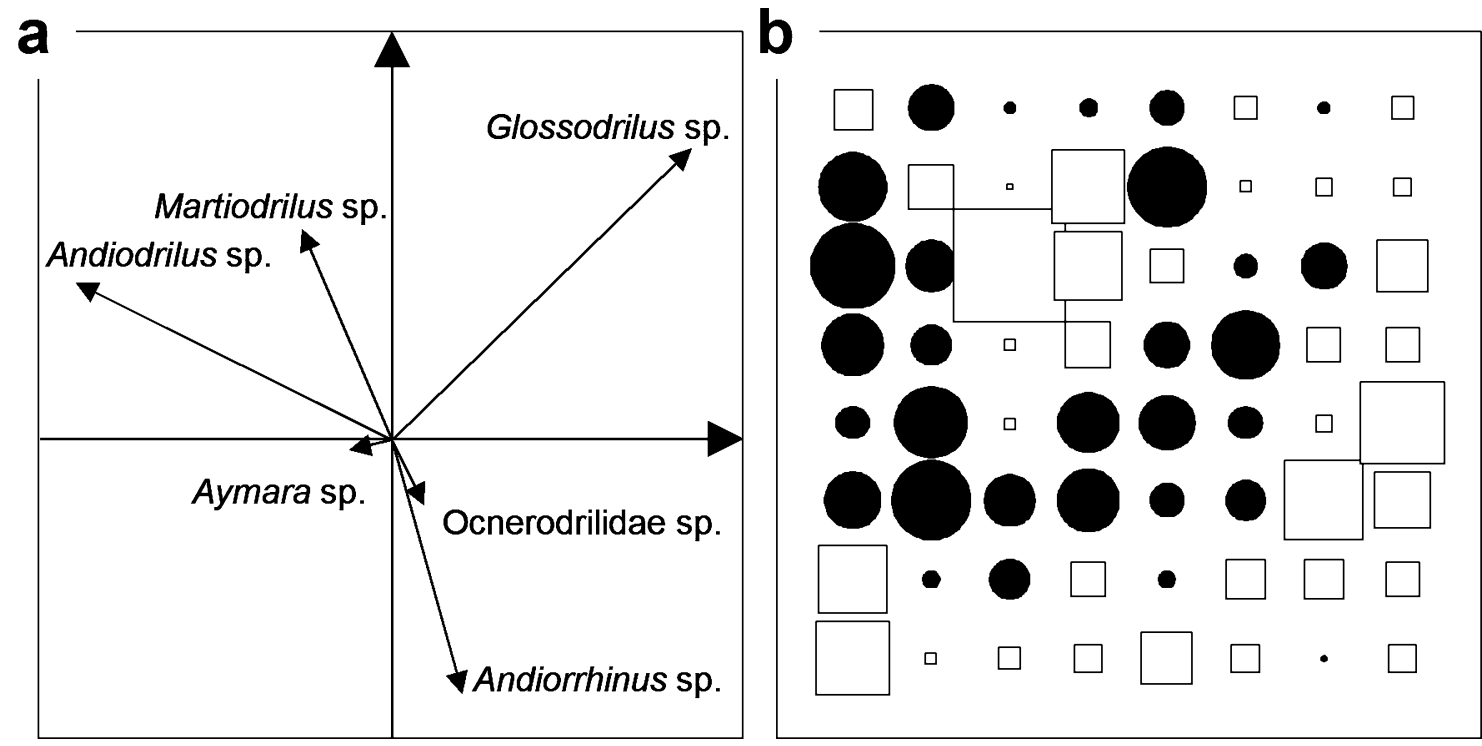

$10 \mathrm{~m}$

Figure 2. Compromise analysis of the species assemblage structure in pasture 1: correlation circle showing the ordination of the variables (species) on the factorial plan defined by the first two axes of the PCA on the compromise matrix (a); maps of the factorial coordinates of the 64 sampling points on the first axis of the PCA on the compromise matrix (b) (circles and squares represent positive and negative scores respectively and the size is proportional to the corresponding value). Modified from Figure 2 in Jiménez et al. (2006) Acta Oecologica 30: 299-311. Copyright (C) by Elsevier. Reprinted with permission of the publisher.

that shared similar spatio-temporal distributions (similar relative position on the first axis) (Figure 2, Table 2). According to Moran's autocorrelograms, sample scores on the first compromise axis were significantly aggregated in space over ranges of 6 to $33 \mathrm{~m}$ (Table 1 ). In each sampled plot, earthworm assemblages thus presented non-random and statistically significant spatio-temporal structure consisting in a juxtaposition of patches characterized by dominant 'patch-level assemblages'. As an example, the compromise analysis of Pasture 1 distinguished $(\mathrm{P}<0.001$, Table 2) a cluster composed of Martiodrilus sp., Andiodrilus sp. and Aymara sp. from another with Glossodrilus sp., Andiorrhinus sp. and Ocnerodrilidae sp. (Figure 2). The six PTAs thus identified 12 patch-level assemblages (Table 2) differentiated within the six plot- level assemblages (i.e. the complete species list occurring in a given plot).

\section{Niche overlap patterns}

Both the Pianka and Czechanowski indices provided very similar results and we thus decided to present only those obtained with the former. Temporal niche overlap was significantly higher than EBC for the majority of patch- and plot-level assemblages (Table 3) and average observed overlaps were unusually high $(\mathrm{P}=0.050$ and $\mathrm{P}=0.002$, respectively). Average SES was significantly higher than 0 at both scales, but was significantly lower in patch- as compared with plot-level assemblages (Table 3).

Table 3. Results of the niche overlap analysis. For each niche axis, we analysed niche overlap patterns for both patch-level assemblages (species with same signs on the first compromise axis, but see Table 2) and plot-assemblages (species present in a given plot). 'Lower tail' and 'Upper tail' indicate the number of assemblages for which the observed Pianka $O_{\text {ik }}$ was respectively less than or greater than predicted by the null model. The number in parentheses indicates the number of assemblages with significant patterns $(\mathrm{P}<0.05$, one-tailed test). Different letters indicate significant differences between observed and $\mathrm{EBC}$ averages $(\mathrm{P}<0.05$, one-way ANOVA). The $\mathrm{P}$ values indicate the probability of accepting the null hypothesis that the standardized effect size (SES) differed from zero, and the $\mathrm{P}^{*}$ values the probability of having no significant difference between SES calculated for patch-level and plot-assemblages (one-way ANOVA).

\begin{tabular}{lcccccccc}
\hline $\begin{array}{l}\text { Niche } \\
\text { dimension }\end{array}$ & Assemblage & Lower tail & Upper tail & $\begin{array}{c}\text { Average obs. } \\
\text { Pianka's O }\end{array}$ & $\begin{array}{c}\text { Average EBC } \\
\text { Pianka's O }\end{array}$ & Average SES & P & $\mathrm{P}^{*}$ \\
\hline Vertical & Patch & $4(0)$ & $8(4)$ & $0.70 \mathrm{a}$ & $0.49 \mathrm{~b}$ & 0.81 & 0.01 & 0.24 \\
Vertical & Plot & $0(0)$ & $6(3)$ & $0.62 \mathrm{a}$ & $0.51 \mathrm{~b}$ & 1.48 & 0.00 & \\
Seasonal & Patch & $2(2)$ & $10(7)$ & $0.75 \mathrm{a}$ & $0.63 \mathrm{~b}$ & 1.35 & 0.03 & 0.02 \\
Seasonal & Plot & $0(0)$ & $6(6)$ & $0.75 \mathrm{a}$ & $0.63 \mathrm{~b}$ & 3.65 & 0.002 & \\
Biometric & Patch & $9(1)$ & $3(0)$ & $0.71 \mathrm{a}$ & $0.75 \mathrm{a}$ & -0.38 & 0.18 & 0.53 \\
Biometric & Plot & $3(0)$ & $3(0)$ & $0.80 \mathrm{a}$ & $0.80 \mathrm{a}$ & -0.07 & 0.73 & \\
\hline
\end{tabular}




\begin{tabular}{|c|c|c|c|c|c|c|c|c|c|}
\hline Biometric trait & Metric & Assemblage & Lower tail & Upper tail & $\begin{array}{c}\text { Average obs. } \\
\text { metric }\end{array}$ & $\begin{array}{c}\text { Average } \mathrm{EBC} \\
\text { metric }\end{array}$ & Average SES & $\mathrm{P}$ & $\mathrm{P}^{*}$ \\
\hline Length & MSL & Patch & $1(0)$ & $6(2)$ & $0.26 a$ & $0.15 b$ & 0.91 & 0.02 & 0.02 \\
\hline Length & MSL & Plot & $5(0)$ & $1(0)$ & $0.04 a$ & $0.05 \mathrm{a}$ & -0.07 & 0.77 & \\
\hline Length & VarSL & Patch & $6(2)$ & $1(0)$ & $0.02 b$ & $0.06 a$ & -0.43 & 0.02 & 0.82 \\
\hline Length & VarSL & Plot & $6(0)$ & $0(0)$ & $0.02 b$ & $0.03 a$ & -0.39 & 0.00 & \\
\hline Weight & MSL & Patch & $1(0)$ & $6(0)$ & $1.17 \mathrm{a}$ & $0.90 \mathrm{a}$ & 0.40 & 0.01 & 0.86 \\
\hline Weight & MSL & Plot & $2(0)$ & $4(1)$ & $0.24 \mathrm{a}$ & $0.19 \mathrm{a}$ & 0.47 & 0.16 & \\
\hline Weight & VarSL & Patch & $6(0)$ & $1(0)$ & $0.17 b$ & $1.05 \mathrm{a}$ & -0.43 & 0.002 & 0.62 \\
\hline Weight & VarSL & Plot & $6(0)$ & $0(0)$ & $0.20 \mathrm{~b}$ & $0.40 \mathrm{a}$ & -0.50 & 0.002 & \\
\hline Diameter & MSL & Patch & $1(0)$ & $6(1)$ & $0.28 \mathrm{a}$ & $0.18 b$ & 0.70 & 0.06 & 0.02 \\
\hline Diameter & MSL & Plot & $5(0)$ & $1(0)$ & $0.04 b$ & $0.06 a$ & -0.31 & 0.02 & \\
\hline Diameter & VarSL & Patch & $6(1)$ & $1(0)$ & $0.05 a$ & $0.10 \mathrm{a}$ & -0.31 & 0.08 & 0.55 \\
\hline Diameter & VarSL & Plot & $6(0)$ & $0(0)$ & $0.02 b$ & $0.05 a$ & -0.46 & 0.001 & \\
\hline
\end{tabular}

At both patch- and plot-levels, vertical niche overlap was almost always significantly higher than EBC, average observed Pianka's $\mathrm{O}_{\mathrm{jk}}$ was higher than mean simulated value $(\mathrm{P}=0.018$ and $\mathrm{P}=0.001$, respectively $)$, and the average SES was significantly higher than 0 (Table 3). Average SES was not significantly different between patch- and plot-level assemblages.

Biometric niche overlap was lower than $\mathrm{EBC}$ in a majority of patch assemblages, but the observed and EBC values were not significantly different, and the SES was not significantly lower than 0 (Table 3). Patterns were mainly random for plot-level assemblages and no significant difference was found when comparing average SES calculated for patch- and plot-level assemblages.

\section{Size distribution patterns}

Patch-level assemblages showed a consistent trend toward over and even spacing of body length (Table 4). MSL was higher than EBC in six of seven cases (with significant individual tests in two of them), average MSL tended to be higher than $\mathrm{EBC}(\mathrm{P}=0.026)$ and had a SES significantly higher than 0. Conversely, plot-level assemblages were characterized by random body length ratio patterns and, when compared with patch-level assemblages, lower average value of the SES calculated for MSL. The VarSL was lower than EBC in the majority of patch and plot assemblages (with two individually significant values for patch-level assemblages), showed an unusually small average $(\mathrm{P}=0.011$ for both patchand plot-level assemblages), and a SES significantly lower than 0 .

Body weight tended to be over spaced in both patchand plot-level assemblages (Table 4): although average observed values were not significantly higher than simulated ones, the corresponding SESs were significantly higher than 0. Average VarSL was also less than EBC $(P=0.001$ and $P=0.009$ for the patch- and plot-levels, respectively), with a SES lower than 0. These patterns should however be viewed with caution, as they were weakly supported by individual matrix analyses which on the whole did not differ from the null model (no significant individual test found for VarSL, and only a single instance found for MSL in Savanna 1). Differences among SES calculated at the patch and at the plot scales were not significant.

Size analysis of body diameter provided results similar with the analysis of body length (Table 4). In patchlevel assemblages MSL was higher than EBC in six of seven cases (with significant individual tests in one of them), average MSL was significantly higher than EBC $(P=0.050)$ and SES was significantly higher than 0. An opposite trend was found in plot-level assemblages, where mean MSL was lower than EBC $(\mathrm{P}=0.025)$, with an average SES significantly lower than 0 and lower than the SES calculated for patch-level assemblages. Although only a single significant individual value was detected, the VarSL was lower than EBC in nearly all of the patch and plot assemblages. For plot-level assemblages, the mean VarSL was significantly lower than expected by chance $(\mathrm{P}=0.001)$, and the corresponding average SES was lower than 0. A similar, although not significant, pattern was found for patch-level assemblages.

\section{DISCUSSION}

The spatial organization of earthworm assemblages in alternating patches characterized by specific species 
assemblages has been found in both tropical and temperate soils (Margerie et al. 2001, Nuutinen et al. 1998, Poier \& Richter 1992, Rossi 2003). Except for savanna 1 , the spatial extent of the patches found in our study (6-22 m) was in the lower range of what is reported in other studies (20-50 m) (Margerie et al. 2001, Rossi 2003). This may be because assemblages were dominated by small and weakly mobile species (Glossodrilus sp., Ocnerodrilidae sp. and Andiodrilus sp.) that aggregate at small spatial ranges (Decaëns \& Rossi 2001, Jiménez et al. 2001, 2006a). The spatial range of patches is thus likely to be context dependent, and aggregation at larger scales is often observed in assemblages with a higher contribution of large and more vagile species, such as in European grasslands (Margerie et al. 2001) or African savannas (Rossi 2003).

The structured proportion of the spatio-temporal variability in earthworm assemblages remained low as indicated by the percentage of inertia associated with the first axes of both the interstructure and compromise analyses. This indicates a high residual variability from the analysis, which may result from different sources including species vagility (Decaëns \& Rossi 2001), sampling error (Jiménez et al. 2006b) and/or small-scale variability (below the minimum inter-sample distance) in species distribution (Rossi \& Nuutinen 2004). All these factors are likely to differ substantially among species, and thus to increase the residual noise in the data matrices. However, despite this residual variability, we observed non-random and statistically significant patterns in the six studied plots. This consistency suggests that the spatio-temporal arrangements of species assemblages are generated by deterministic assembly rules rather than by random events.

The reason why patch-level assemblages differed so much in composition among plots of the same habitat type is an interesting question that will require additional information to be elucidated. Differences between species assemblages of apparently similar habitats might be due to slight environmental differences that may confer a slight selective advantage to colonists of particular species (Diamond 1975). In our case, however, the detailed study of the sampled plots provided no evidence that this mechanism may account for the observed differences in assemblage composition (Decaëns \& Rossi 2001, Jiménez et al. 2001, 2006a). Alternatively, chance in the form of random historical events (e.g. chronological order in colonization events) might play a large role in building up non-identical assemblages that represent stable equilibria (Diamond 1975). Any given patch-assemblage would thus represent one of many possible, alternative, stable assemblages that could be constructed on paper from the same species pool.

Despite the widely accepted idea that earthworm species show a high degree of niche partitioning with regards to vertical distribution (Bouché 1977, Lavelle \& Spain 2001), we reported a niche overlap according to this dimension higher than EBC. This is an unexpected result, as the local pool comprises species of different ecological guilds that are supposed to differ substantially in their yearly average vertical distribution. Similarly, we found a higher seasonal niche overlap than EBC, in accordance with the review of Schoener (1974) who concluded that animals often segregate along food and habitat dimensions but rarely along temporal niche axes. These results suggest strong constraints on membership in assemblages (Weiher \& Keddy 1995). Ecological theory predicts that environmental conditions acting as strong habitat filters may induce an underdispersion of the traits associated with these pressures (Keddy 1992, Keddy \& Weiher 1999, Weiher \& Keddy 1995). The low levels of organic matter, its concentration in the superficial soil layers and the high seasonality of rainfall may for example select earthworm species that display dormancy during the dry season, concentrate their activities during the rainy period and/or locate their foraging activities in the first $20 \mathrm{~cm}$ of the soil profile (Jiménez \& Decaëns 2000, Jiménez et al. 2000). Alternatively, niche overlap SES were on average significantly lower in patches than in plot-assemblages, which suggests that competition is reduced in patches by limiting ecological similarity between species that co-exist at this scale.

The idea that co-existing species should differ in morphology in order to reduce resource use overlap is supported by a great amount of empirical evidence (Dayan \& Simberloff 2005, Weiher \& Keddy 1995). For instance, patterns of limiting similarity, such as ecological and community-wide character displacements, have been reported for many groups of vertebrates but more rarely for invertebrates (see review by Dayan \& Simberloff 2005). Regular spacing of body size and morphometric overdispersion was however reported in assemblages of molluscs (Barker \& Mayhill 1999, Chiba 2004, Grudemo \& Johannesson 1999), crustaceans (Marchinko et al. 2004), beetles (Brandl \& Topp 1985, Satoh et al. 2003, Sota et al. 2000), and ants (Gotelli \& Ellison 2002, Nipperess \& Beattie 2004). The only case study dealing with earthworms, an example of ecological character displacement in sympatry between congeneric species in Mexico (Fragoso \& Rojas 1997), suggests that body shape is directly related to resource utilization. The relationship between species biometric features and life history strategies, and in particular resource uses, is also central in most eco-morphological classifications that are classically recognized in earthworm studies (Bouché 1977, Lavelle 1997). Despite the non-significance of the results obtained for biometric niche overlap, our data support this idea by demonstrating that a minimum level of morphometric differentiation in body sizes is necessary to allow species to co-exist in a given patch-level assemblage. 
Competition may however generate different patterns according to the spatial scale considered. We found that body weight was significantly overdispersed and constant among species at both the plot and patch scales, while body length shows a similar pattern at the patch scale only. This suggests that both attributes may be directly related to different features of species feeding habits. Body weight is, for example, known to reflect the quality of the resource ingested by geophagous species (Lavelle 1981): small species are often specialized for organicrich substrates (e.g. litter, root exudates, vertebrate faeces, etc.), while larger ones usually ingest a variable proportion of soil with lower organic content. Although litter-feeding species may not fully match this model, most earthworms of Carimagua were described to feed at least partly on soil (Jiménez et al. 1998b, Mariani et al. 2001), and different weights among species may thus reflect differences in the organic content of their food substrate. Alternatively, species body length was reported to reflect the size of the ingested soil particles, although no general pathway for this relationship has been pointed to date (Blanchart et al. 1997, Lowe \& Butt 2003). Differentiation of trophic niches according to both the organic content and particle size of the ingested material among earthworm species has been reported in a number of other studies (Curry \& Schmidt 2007). Our results thus suggest that species may co-exist in a given plot thanks to a minimum level of niche partitioning with regards to the organic content of their feeding substrate. At a lower scale, assemblage patchiness would result from spatial segregation between species competing for similar particle size classes, and from within-patch complementarity between species of different body size. This last hypothesis was first proposed by Rossi (2003) for earthworm assemblages of savanna soils of Côte d'Ivoire, and is supported in our results by some conspicuous trends in pairwise relationships among species. For example, the large-sized Martiodrilus sp. is associated in four of six cases with the small Ocnerodrilidae sp., which feeds upon the large casts produced by the former species (Jiménez et al. 2006a). Conversely, Andiodrilus sp. and Glossodrilus sp., two potentially competing geophagous species with relatively similar biometric features, are segregated in different patches in four cases of six (Table 2). Although these patterns of coexistence/segregation are not strong, it is reasonable to interpret them as being consistent with the overall conclusion that the spatial structure of earthworm assemblages is non-random and mainly reflects competition versus complementarity interactions between species.

Our results broadly demonstrate that competition influences assemblage structure more strongly within patches than within plots, and therefore plays a significant role in the spatial patterning of earthworm assemblages below the plot scale. This supports the conclusions of a recent study that pointed to competition as the main assembly constraint in earthworm assemblages of north-western France (Decaëns et al. 2008). The exact mechanisms involved in earthworm interspecific interactions are however still poorly known. Dalby et al. (1998) found that competition among species may result from direct cocoon consumption. Such intra-guild predation has been reported for a number of other animals, e.g. birds (Hakkarainen \& Korpimaeki 1996, Spooner et al. 1996), fish (Garner 1996), salamanders (Roudebush \& Taylor 1987) and scorpions (Polis \& McCormick 1987). It is assumed to increase the competitiveness of the predating competitor through an enhanced nitrogen intake (Matsumura et al. 2004). Additionally, earthworms are ecosystem engineers (sensu Jones et al. 1994) able to physically modify their environment, thus altering resource availability for other species. Soil engineering has been reported as a possible mechanism of interspecific competition among earthworm species or between earthworms and other groups of organisms. As an example, deep-burrowing species may deprive surface-dwellers of their habitat and trophic substrate when actively burying litter into the soil (Dalby et al. 1998, Hendrix et al. 2006). Geophagous species may also interact, either positively or negatively, with each other by modifying the size distribution of soil aggregates, and therefore their availability as a readily ingestible substrate for other species (Blanchart et al. 1997, Lowe \& Butt 2003). As proposed by Hastings et al. (2007), more research should be undertaken to improve our comprehension and to quantify the role of earthworm engineering activities relative to other processes such as resource competition and trophic interactions.

In conclusion, our study supports the model of Weiher \& Keddy (1995) that species traits associated with meeting the challenges of competition adversity (morphometric traits) are overdispersed, while those associated with environmental pressure (vertical and temporal distribution) are underdispersed. The assembly rules that emerge from our results are: (1) at the plot scale, body weights of co-existing earthworm species show a significant trend toward overdispersion and low variance of segment length, seasonal and vertical niche overlap are higher than EBC and species are aggregated in discrete patches; (2) at the scale of these patches, niche overlap is reduced when compared with the plot scale, and body length and diameter of co-existing species are overdispersed and display low variance in segment length.

\section{ACKNOWLEDGEMENTS}

We wish to thank all the persons who contributed to some extent in the achievement of this work. We are 
particularly grateful to the former team of the 'Unidad Suelos y Nutrición de Plantas' (CIAT): R. Thomas, E. Amézquita, G. Rippstein, I. Rao, R. Vera and D. K. Friesen for their valuable technical and scientific help, C. G. Meléndez, I. Corrales, J. Galvis, H. Alarcón, N. Betancourt, L. Soto and H. Unda for their participation to field sampling, J. García, G. Murcia, S. Rojas and J. Soto for their help and friendship in the field and the management staff of the Carimagua Research Station (CIAT-CORPOICA). Thanks to S. James (Kansas University) and K. R. Butt (University of Central Lancashire) for their comments and language corrections. Financial support was provided by the DIVERSITAS and the MAS, SWNM programmes.

\section{LITERATURE CITED}

ALBRECHT, M. \& GOTELLI, N. J. 2001. Spatial and temporal niche partitioning in grassland ants. Oecologia 126:134-141.

BARKER, G. M. \& MAYHILL, P.C. 1999. Patterns of diversity and habitat relationships in terrestrial mollusc communities of the Pukeamaru Ecological District, northeastern New Zealand. Journal of Biogeography 26:215-238.

BAROT, S., ROSSI, J.-P. \& LAVELLE, P. 2007. Self-organization in a simple consumer-resource system, the example of earthworms. Soil Biology and Biochemistry 39:2230-2240.

BLANCHART, E., LAVELLE, P., BRAUDEAU, E., LE BISSONNAIS, Y. \& VALENTIN, C. 1997. Regulation of soil structure by geophagous earthworm activities in humid savannas of Côte d'Ivoire. Soil Biology and Biochemistry 29:431-439.

BOUCHÉ, M. B. 1977. Statégies lombriciennes. Pp. 122-132 in Lohm, U. \& Persson, T. (eds.). Soil organisms as components of ecosystems. Ecological Bulletin, Stockholm.

BOYD, J. M. 1957. Comparative aspects of the ecology of Lumbricidae on grazed and ungrazed natural maritime grassland. Oikos 8:107121.

BRANDL, R. \& TOPP, W. 1985. Size structure of Pterostichus spp. (Carabidae): aspects of competition. Oikos 44:234-238.

BROWN, W. L. \& WILSON, E. O. 1956. Character displacement. Systematic Zoology 5:49-64.

CHIBA, S. 2004. Ecological and morphological patterns in communities of land snails of the genus Mandarina from the Bonin Islands. Journal of Evolutionary Biology 17:131-143.

CONNELL, J. H. 1983. On the prevalence and relative importance of interspecific competition: evidence from field experiments. American Naturalist 122:661-696.

CURRY, J. P. \& SCHMIDT, O. 2007. The feeding ecology of earthworms - a review. Pedobiologia 50:463-477.

DALBY, P. R., BAKER, G. H. \& SMITH, S. E. 1998. Competition and cocoon consumption by the earthworm Aporrectodea longa. Applied Soil Ecology 10:127-136.

DARWIN, C. 1881. The formation of vegetable mould through the action of worms with observations of their habits. Murray, London. 153 pp.

DAYAN, T. \& SIMBERLOFF, D. 2005. Ecological and community-wide character displacement: the next generation. Ecology Letters 8:875894.
DECAËNS, T. 1999. Rôle fonctionnel et réponses aux pratiques agricoles des vers de terre et autresingénieursécologiques dans les savanes colombiennes. Doctoral thesis, Université Paris VI - Pierre et Marie Curie. $374 \mathrm{pp}$.

DECAËNS, T. \& JIMÉNEZ, J. J. 2002. Earthworm communities under an agricultural intensification gradient in Colombia. Plant and Soil 240:133-143.

DECAËNS, T. \& ROSSI, J. P. 2001. Spatio-temporal structure of earthworm community and soil heterogeneity in a tropical pasture. Ecography 24:671-682.

DECAËNS, T., MARGERIE, P., HEDDE, M. \& BUREAU, F. 2008. Assembly rules within earthworm communities in North-Western France - a regional analysis. Applied Soil Ecology 39:321-335.

DIAMOND, J. M. 1975. Assembly of species communities. Pp. 342444 in Cody, M. L. \& Diamond, J. M. (eds.). Ecology and evolution of communities. Harvard University Press, Cambridge.

ETTEMA, C. H. \& WARDLE, D. A. 2002. Spatial soil ecology. Trends in Ecology and Evolution 17:177-183.

ETTEMA, C. H., RATHBUN, S. L. \& COLEMAN, D. C. 2000. On spatiotemporal patchiness and the coexistence of five species of Chronogaster (Nematoda: Chronogasteridae) in a riparian wetland. Oecologia 125:444-452.

FEELEY, K. 2003. Analysis of avian communities in Lake Guri, Venezuela, using multiple assembly rule models. Oecologia 137:104113.

FEINSINGER, P., SPEARS, E. E. \& POOLE, R. W. 1981. A simple measure of niche breadth. Ecology 62:27-32.

FRAGOSO, C. \& ROJAS, P. 1997. Size shift in the Mexican earthworm species Balanteodrilus pearsei (Megascolecidae, Acanthodrilini): a possible case of character displacement. Soil Biology and Biochemistry 29:237-240.

GARNER, P. 1996. Microhabitat use and diet of O+ cyprinid fishes in a lentic, regulated reach of the River Great Ouse England. Journal of Fish Biology 48:367-382.

GOLDBERG, D. E. \& BARTON, A. M. 1992. Patterns and consequences of interspecific competition in natural communities: a review of field experiments with plants. American Naturalist 139:771801.

GOTELLI, N. J. 2001. Research frontiers in null model analysis. Global Ecology and Biogeography 10:337-343.

GOTELLI, N. J. \& ELLISON, A. M. 2002. Assembly rules for New England ant assemblages. Oikos 99:591-599.

GOTELLI, N. J. \& GRAVES, G. R. 1996. Null models in ecology. Smithsonian Institution Press, Washington, DC. 368 pp.

GOTELLI, N. J. \& McCABE, D. J. 2002. Species co-occurrence: a metaanalysis of J. M. Diamond's assembly rules model. Ecology 83:20912096.

GRUDEMO, J. \& JOHANNESSON, K. 1999. Size of mudsnails, Hydrobia ulvae (Pennant) and H. ventrosa (Montagu), in allopatry and sympatry: conclusions from field distributions and laboratory growth experiments. Journal of Experimental Marine Biology and Ecology 239:167-181.

GUILD, W. J. M. 1951. The distribution and population density of earthworms (Lumbricidae) in Scottish pasture fields. Journal of Animal Ecology 20:88-97. 
HAKKARAINEN, H. \& KORPIMAEKI, E. 1996. Competitive and predatory interactions among raptors: an observational and experimental study. Ecology 77:1134-1142.

HASTINGS, A., BYERS, J. E., CROOKS, J. A., CUDDINGTON, K., JONES, C. G., LAMBRINOS, J. G., TALLEY, T. S. \& WILSON, W. G. 2007. Ecosystem engineering in space and time. Ecology Letters 10:153164.

HENDRIX, P. F., BAKER, G. H., CALLAHAM, M. A., DAMOFF, G. A., FRAGOSO, C., GONZALEZ, G., JAMES, S. W., LACHNICHT, S. L., WINSOME, T. \& ZOU, X. 2006. Invasion of exotic earthworms into ecosystems inhabited by native earthworms. Biological Invasions 8:1287-1300.

HERNÁNDEZ, P., FERNÁNDEZ, R., NOVO, M., TRIGO, D. \& DÍAZ-COSÍN, D. J. 2007. Geostatistical and multivariate analysis of the horizontal distribution of an earthworm community in El Molar (Madrid, Spain). Pedobiologia 51:13-21.

HOFER, U., BERSIER, L. F. \& BORCARD, D. 2004. Relating niche and spatial overlap at the community level. Oikos 106:366-376.

HUTCHINSON, G. E. 1959. Homage to Santa Rosalia of why are there so many kinds of animals? American Naturalist 93:145-159.

JIMÉNEZ, J. J. 1999. Dinámica de las poblaciones y estructura de las comunidades de lombrices de tierra de las sabanas naturales y perturbadas de los Llanos Orientales de Colombia. Doctoral Thesis, Universidad Complutense de Madrid, Madrid. 311 pp.

JIMÉNEZ, J. J. \& DECAËNS, T. 2000. Vertical distribution of earthworms in grassland soils of the Colombian Llanos. Biology and Fertility of Soils 32:463-473.

JIMÉNEZ, J. J. \& ROSSI, J. P. 2006. Spatial dissociation between two endogeic earthworms in the Colombian "Llanos". European Journal of Soil Biology 42:S218-224.

JIMÉNEZ, J. J., MORENO, A. G., LAVELLE, P. \& DECAËNS, T. 1998a. Population dynamics and adaptive strategies of Martiodrilus carimaguensis (Oligochaeta, Glossoscolecidae), a native species from the well-drained savannas of Colombia. Applied Soil Ecology 9:153160.

JIMÉNEZ, J. J., MORENO, A. G., DECAËNS, T., LAVELLE, P., FISHER, M. \& THOMAS, R. J. 1998b. Earthworm communities in native savannas and man-made pastures of the Eastern Plains of Colombia. Biology and Fertility of Soils 28:101-110.

JIMÉNEZ, J. J., BROWN, G. G., DECAËNS, T., FEIJOO, A. \& LAVELLE, P. 2000. Differences in the timing of diapause and patterns of aestivation in tropical earthworms. Pedobiologia 44:677-694.

JIMÉNEZ, J. J., ROSSI, J. P. \& LAVELLE, P. 2001. Spatial distribution of earthworms in acid-soil savannas of the eastern plans of Colombia. Applied Soil Ecology 17:267-278.

JIMÉNEZ, J. J., DECAËNS, T. \& ROSSI, J. P. 2006a. Stability of the spatiotemporal distribution and niche overlap in neotropical earthworm assemblages. Acta Oecologica 30:299-311.

JIMÉNEZ, J. J., LAVELLE, P. \& DECAËNS, T. 2006b. The efficiency of soil hand-sorting in assessing the abundance and biomass of earthworm communities. Its usefulness in population dynamics and cohort analysis studies. European Journal of Soil Biology 42:S225S230.

JONES, C. G., LAWTON, J. H. \& SHACHAK, M. 1994. Organisms as ecosystem engineers. Oikos 69:373-386.
KEDDY, P. A. 1992. Assembly and response rules: two goals for predictive community ecology. Journal of Vegetation Science 3:157164.

KEDDY, P. A. \& WEIHER, E. 1999. The scope and goals of research on assembly rules. Pp. 1-20 in Weiher, E. \& Keddy, P. A. (eds.). Ecological assembly rules. Perspectives, advances, retreats. Cambridge University Press, Cambridge.

KROONENBERG, P. M. 1989. The analysis of multiple tables in factorial ecology. III. Three mode principal component analysis: "analyse triadique complète”. Acta Oecologica 10:245-256.

LAVELLE, P. 1981. Statégies de reproduction chez les vers de terre. Acta CEcologica Ecologia Generalis 2:117-133.

LAVELLE, P. 1996. Diversity of soil fauna and ecosystem function. Biology International 33:3-16.

LAVELLE, P. 1997. Faunal activities and soil processes: adaptive strategies that determine ecosystem function. Advances in Ecological Research 27:93-132.

LAVELLE, P. 2002. Functional domains in soils. Ecological Research $17: 441-450$.

LAVELLE, P. \& SPAIN, A. V. 2001. Soil ecology. Kluwer Academic Publishers, Dordrecht. $654 \mathrm{pp}$.

LAVELLE, P., DECAËNS, T., AUBERT, M., BAROT, S., BLOUIN, M., BUREAU, F., MARGERIE, P., MORA, P. \& ROSSI, J. P. 2006. Soil invertebrates and ecosystem services. European Journal of Soil Biology 42:S3-S15.

LEGENDRE, P. \& FORTIN, M. J. 1989. Spatial pattern and ecological analysis. Vegetatio 80:107-138.

LOWE, C. N. \& BUTT, K. R. 2003. Influence of food particle size on interand intra-specific interactions of Allolobophora chlorotica (Savigny) and Lumbricus terrestris. Pedobiologia 47:574-577.

MACARTHUR, R. H. \& LEVINS, R. 1967. The limiting similarity, convergence, and divergence of coexisting species. American Naturalist 10:377-385.

MARCHINKO, K. B., NISHIZAKI, M. T. \& BURNS, K. C. 2004. Community-wide character displacement in barnacles: a new perspective for past observations. Ecology Letters 7:114120.

MARGERIE, P., DECAËNS, T., BUREAU, F. \& ALARD, D. 2001. Spatial distribution of earthworm species assemblages in a chalky slope of the Seine Valley (Normandy, France). European Journal of Soil Biology 37:291-296.

MARIANI, L., BERNIER, N., JIMÉNEZ, J. J. \& DECAËNS, T. 2001. Régime alimentaire d'un ver de terre anécique des savanes colombiennes: une remise en question des types écologiques. Comptes Rendus de l'Académie des Sciences de Paris. Série III - Sciences de la Vie 324:733742.

MATSUMURA, M., TRAFELET-SMITH, G. M., GRATTON, C., FINKE, D. L., FAGAN, W. F. \& DENNO, R. F. 2004. Does intraguild predation enhance predator performance? A stoichiometric perspective. Ecology $85: 2601-2615$.

NIPPERESS, D. A. \& BEATTIE, A. J. 2004. Morphological dispersion of Rhytidoponera assemblages: the importance of spatial scale and null model. Ecology 85:2728-2736.

NUUTINEN, V., PITKÄNEN, J., KUUSELA, E., WIDBOM, T. \& LOHILAHTI, H. 1998. Spatial variation of an earthworm community 
related to soil properties and yield in a grass-clover field. Applied Soil Ecology 8:85-94.

PHILLIPSON, J., ABEL, A., STEEL, J. \& WOODELL, S. R. J. 1976. Earthworms and the factors governing their distribution in an English beechwood. Pedobiologia 16:258-285.

PIANKA, E. R. 1973. The structure of lizard communities. Annual Review of Ecology and Systematics 4:53-74.

PIELOU, D. P. \& PIELOU, E. C. 1968. Association among species in infrequent occurrence: the insect and spider fauna of Polyporus betulinus (Bulliard) Fries. Journal of Theoretical Biology 21:202216.

POIER, K. R. \& RICHTER, J. 1992. Spatial-distribution of earthworms and soil properties in an arable loess soil. Soil Biology and Biochemistry 24:1601-1608.

POLIS, G. A. \& MCCORMICK, S. J. 1987. Intraguild predation and competition among desert scorpions. Ecology 68:332-343.

ROSSI, J. P. 2003. The spatiotemporal pattern of a tropical earthworm species assemblage and its relationship with soil structure. Pedobiologia 47:497-503.

ROSSI,J.P.\& LAVELLE, P. 1998. Earthworm aggregation in the savanna of Lamto (Côte d'Ivoire). Applied Soil Ecology 7:195-199.

ROSSI, J.P. \& NUUTINEN, V. 2004. The effect of sampling unit size on the perception of the spatial pattern of earthworm (Lumbricus terrestris L.) middens. Applied Soil Ecology 27:189-196.

ROSSI, J. P., LAVELLE, P. \& ALBRECHT, A. 1997. Relationships between spatial pattern of the andogeic earthworm Polypheretima elongata and soil heterogeneity. Soil Biology and Biochemistry 29:485488 .

ROUDEBUSH, R. E. \& TAYLOR, D. H. 1987. Behavioral interactions between two desmognathine salamander species: importance of competition and predation. Ecology 68:1453-1458.

SATOH, A., UEDA, T., ENOKIDO, Y. \& HORI, M. 2003. Patterns of species assemblages and geographical distributions associated with mandible size differences in coastal tiger beetles in Japan. Population Ecology 45:67-74.
SCHOENER, T. W. 1974. Resource partitioning in ecological communities. Science 185:27-39.

SOKAL, R. R. \& ODEN, N. L. 1978. Spatial autocorrelation in biology. 1. Methodology. Biological Journal of the Linnean Society 10:199-228.

SOKAL, R. R. \& ROHLF, F. J. 1995. Biometry: the principles and practice of statistics in biological research (third edition). W. H. Freeman and Company, New York.

SOTA, T., TAKAMI, Y., KUBOTA, K., UJIIE, M. \& ISHIKAWA, R. 2000. Interspecific body size differentiation in species assemblages of the carabid subgenus Ohomopterus in Japan. Population Ecology 42:279291.

SPOONER, A., PRIBIL, S. \& PICMAN, J. 1996. Why do gray catbirds destroy eggs in nests of other birds? Experimental tests of alternative hypotheses. Canadian Journal of Zoology 74:1688-1695.

THIOULOUSE, J. \& CHESSEL, D. 1987. Les analyses multitableaux en écologie factorielle. I. De la théorie d'état à la typologie de fonctionnement par l'analyse triadique. Acta Ecologica Ecologia Generalis 8:463-480.

THIOUlOUSE, J., CHESSEL, D., DOLÉDEC, S. \& OLIVIER, J. M. 1997. ADE-4: a multivariate analysis and graphical display software. Statistics and Computing 7:75-83.

WARDLE, D. A. 2002. Communities and ecosystems - linking the aboveground and belowground components. Princeton University Press, Princeton.

WEIHER, E. \& KEDDY, P. A. 1995. Assembly rules, null models, and trait dispersions: new questions from old patterns. Oikos 74:159-164.

WEIHER, E., ClARKE, G. D. P. \& KEDDY, P. A. 1998. Community assembly rules, morphological dispersion, and the coexistence of plant species. Oikos 81:309-322.

WHALEN, J. K. \& COSTA, C. 2003. Linking spatio-temporal dynamics of earthworm populations to nutrient cycling in temperate agricultural and forest ecosystems. Pedobiologia 47:801-806.

WILSON, J. B. \& HABIBA, G. 1995. Limitation to species coexistence: evidence for competition from field observations, using a patch model. Journal of Vegetation Science 6:369-376. 